\title{
The Phenomenon of Corruption in the South African Public Sector: Challenges and Opportunities
}

\author{
Manyaka R.K \\ Department of Public Administration, University of Limpopo, South Africa \\ Khutso.manyaka@ul.ac.za \\ Nkuna N.W \\ Department of Public Administration, University of Limpopo, South Africa \\ Nghamula.nkuna@ul.ac.za
}

Doi:10.5901/mjss.2014.v5n27p1572

\begin{abstract}
There is a great recognition by Public Administration academics, practitioners and civil society alike that corruption in the public sector has an adverse impact on service delivery. This emanates from the understanding that corruption does not only undermine the development goals of the country, but also that it hits the poor the most as resources that are meant to assist them out of their nervous conditions are diverted to the benefits of the few corrupt elites. Under these circumstances, structural inequalities, which have come to define and characterise the society in post-apartheid South Africa, are reinforced. This is evident in the fact that the rich continues to get richer as the poor get even poorer. This is a condition which is not conducive for social and political stability as well as sustainable development. It is largely because of this consideration that effective anticorruption work is critical for promoting good governance in a developmental state such as what South Africa aspires to be. The article argues that although the South African public sector has a sound legislative framework and strategies for combating corruption, challenges such as the weaker application of the legislation and oversight mechanisms; insufficient political will; political deployments, and an absence of meritocratic systems provide opportunities for unethical, fraudulent and/or corrupt activities to thrive. To this end, the article presents an overview of the phenomenon of corruption in the South African public sector with the view of identifying the causes of corruption; the challenges of combating corruption as well as the implications these challenges pose for service delivery. The article concludes by making some recommendations on how to resolve the scourge of corruption.
\end{abstract}

\section{Introduction}

The phenomenon of corruption is a universal problem (Myint, 2000; Mafunisa, 2007; Ruhiiga, 2009; Soliman \& Cable, 2011) and considered particularly troublesome in developing nations (De Graaf, 2007; Denoeux, 2007) like that of South Africa. Corruption is problematic for most developing nations primarily because resources that are meant to achieve socio-economic and developmental objectives are, often times than not, diverted to the benefit of few corrupt elites thereby undermining the developmental goals of these nations. It is therefore, not surprising that there is a growing worldwide concern over the phenomenon of corruption, where in response, the United Nations (UN) has in 2003 adopted the Convention Against Corruption (CAC) thereby effectively obliging its 148 signatories to adopt anti-corruption measures (Soliman \& Cable, 2011). With the increased awareness of the detrimental effects of corruption, it has become a dominant subject in the media, academia, and among policy makers, in civil society organisations and business as well as among members of the public in general. Corruption is a problem which has engaged the attention of analysts as well as the public at large from the time of the emergence of civil societies in ancient times to the complex polities of the present day (Balachandrudu, 2006). It is worth noting however that even though there has been an increase public interest and concerns over corruption, which have resulted in a large amount of scholarly research on the subject (Myint, 2000; De Graaf, 2007), the phenomenon still remains problematic and challenging for most developing nations including South Africa. It is not surprising therefore that the phenomenon of corruption was a recurrent theme and served as a campaigning tool used by various political parties in South Africa's run-up to 2014 National and Provincial elections. This is consistent with the argument raised by Kroukamp (2006: 209) in that South African citizens are increasingly rating "corruption as a major concern" within the public sector. It is understandable therefore that all sectors of the society are 
increasingly becoming concerned with the seeming rise of the scourge of corruption rightly because it threatens the livelihood of everyone by crippling service delivery, undermining economic growth and eroding the legitimacy and the functioning of the state. Hence it is not surprising when Ahmad (2004) asserts that corrupt transactions always create winners and losers from the deal. Yet it is important to concede that the more we know about the causes of corruption, the better we can decide which policy instruments to use to combat corruption (Graaf, 2007).

Kroukamp (2006:211) argues that since the advent of the democratic dispensation, government initiated and implemented the most innovative and sophisticated legislative and policy frameworks for combating corruption in the South African public sector (see also Mle \& Maclean, 2011; Manyaka \& Sebola, 2013). The Constitution of the Republic of South Africa 1996 sets the tone by prescribing the basic principles that should serve as guiding tools for public functionaries in executing their duties. One of these principles holds that "the promotion and maintenance of a high standard of professional ethics" must be prioritised (Section 195 of the Constitution of the Republic of South Africa, 1996). The Constitution further established what is referred to as Chapter nine (9) institutions such as the Offices of the Public Protector and the Auditor General (AG) with the purpose of promoting democracy by way of protecting the public sector against unethical and corrupt practices. In 2001, South African public sector, civil society and business launched a collaborative effort by forming a National Anti-Corruption Forum (NACF) in order to fight the scourge of corruption in unison. This collaborative effort culminated in the adoption of the 2002 Public Service Anti-Corruption Strategy by the government as a resolution from NACF. Amongst its strategic considerations the following are most important:

- The criminalisation of corruption;

- Ensuring that all Public Service departments are required to have minimum anti-corruption capacity requirements;

- Improved access to report wrongdoing and protection of whistle-blowers and witnesses

The criminalisation of corrupt practices found resonance in public sector in 2004, when the Prevention and Combating of Corrupt Activities Act, Act No. 12 of 2004 was promulgated, thereby effectively rendering corruption a criminal offense with the maximum sentence of 15 years imprisonment. In the same year, a National Anti-Corruption hotline was set-up for whistle blowers as a measure to increase access to report wrong doing. Despite all these advances, corruption in the South African public sector is still a major challenge (Manyaka \& Sebola, 2013). The other strategic consideration of the Public Service Anti-Corruption strategy was the requirement for the establishment of minimum anti-corruption capacities in all National and Provincial departments and their entities. The purpose was to strengthen the capabilities of these departments to effectively fight corruption. According to the results Minimum AntiCorruption Capacity (MACC) Requirements audit, a joint initiative of the DPSA and the office of the Public Service Commission, most departments in the South African public service are still without minimum capacities required to effectively fight corruption (DPSA, 2010). The same stance is reiterated by the office of the Public Service Commission (PSC) and the Auditor General (AG) in their annual reports that stretches the period of 2010 to 2013. It is for this reason that this article attempts to look into the challenges in the fight against corruption and opportunities which, if fully exploited, could result in the substantial reduction of corruption and consequently improved service delivery. The article commences by providing a brief conceptualisation of the notion of corruption. This is followed by the identification of the common causes of corruption in the South African public sector; the discussion on the significance of strengthening and consolidating efforts to fight the scourge of corruption. The article concludes by proposing some interventions that could be used to effectively combat corruption in the South African public sector.

\section{Conceptualising the Notion of Corruption}

According to Mafunisa (2007: 261) "the concept of corruption can be defined in different ways depending on the point of view or type of approach followed". In most cases, the term is loosely understood by ordinary and high profile people and institutions alike. For example, the notion of corruption can be broadly understood as the abuse of the public office for private gain. According to Pauw, Woods, Van der Linde, Fourie \& Visser (2009: 344), the term can be defined as the abuse of position for personal gain or for the benefit of an individual or a group to whom one owes allegiance. They view corruption as a two way process that involve members of both the public and the private sector, who engage in illegitimate and unethical actions that diminish the country's economic prospects and degrade social and political institutions. To this end, the term corruption, in the context of public sector, refers to "a diversion from the set or accepted norms in the course of performance of one's public duties, for selfish personal gain" (Bitarabeho, 2003). De Graaf (2007) defines government corruption as the sale by government officials of government property for personal gain. For example, government officials often collect bribes for providing permits and licenses, for giving passage through customs, or for prohibiting the entry of competitors. In these cases they charge personally for goods that the state officially owns. A 
spectrum of corrupt behaviour exists, from petty corruption, which may include bribes or illicit payments for routine bureaucratic processes, to grand corruption, which involves leaders, politicians, and senior officials diverting public resources on a large scale to serve their private interests. Both petty and grand corruption damage public trust and accountability, and distort the allocation of public resources, thus reducing economic growth and increasing poverty (Australian Agency for International Development (AusAid), 2007).

Nonetheless this article will not dwell much on the subject of definition as it is not so intended. However, for the purpose of this article, the term corruption will be used to refer to the exercise of authority influenced by the promise or actual presentation of personal gratification as opposed to honest and objective exercise of authority. In terms of the Prevention and Combating of Corrupt Activities Act, Act No. 12 of 2004, corruption occurs when person A gives person B in position of authority something called "gratification" to influence person B to use his influence to the benefit of person A. This applies and may occur in any sector, be it business or civil society, it is not exclusive to the public sector. It is important however to note that the article focuses only on examining the phenomenon of corruption in the public sector because of its negative impact on service delivery. Corruption, in all its manifestations, sometimes takes the form of state capture, a process of collusion between the private sector and politicians or public officials for their own private, mutual benefit. Commonly, corruption manifests itself in various forms. This may include but not limited to the following: - bribery, nepotism, embezzlement, extortion, nepotism, fraud, theft and conflict of interests (Kanyane, 2005; Mafunisa, 2007; Edwards, 2008; Ruhiiga, 2009).

According to the Transparency Internationals' Global Corruption Barometer (2013), there is a high percentage 62\% of people who feel that from 2007-2010, the level of corruption in the country has increased substantially, while $24 \%$ are of the opinion that level of corruption has in actual fact decreased and only $14 \%$ argue that it has somewhat remained the same. It is exceedingly difficult for one to draw a more reliable conclusion on the level of corruption from the above mentioned statistics. This is understandable because the Transparency International is not so much transparent about the methodology and the sample size it employed to obtain such statistics. However, it is important to note that perceptions of unethical behaviour are widely reported in the media daily. And as a result, it becomes difficult to ignore perception of corruption in the country. To this end, it is important to identify the causes of corruption that are peculiar to the South African public sector in order to obtain a clear understanding of the nature and extent of corruption in the country.

\section{Causes of Corruption in the South African Public Sector}

Van der Merwe (2006: 32) argues that an "effective anti-corruption measures should consider both the nature and causes of public sector corruption". The causes of corruption in South Africa are contextual (Kroukamp, 2006:208) hence Caiden (2001) in De Graaf (2007) contends that the complexity of the phenomenon makes it impossible to provide a comprehensive account of the causes as manifestation is within a political landscape. While the causes of corruption might differ from one environment to another, the following are considered prevalent in the South African Public Sector: weaker application of the legislation and oversight mechanisms; insufficient Political will; political deployments, low wages, and an absence of meritocratic systems.

\subsection{Weaker application of the legislation and oversight mechanisms}

The draft Public Sector Integrity Management Framework (2011) noted that a myriad of challenges are apparent in the public service as far as the implementation of ethical and anti-corruption measures is concerned, chief among them is non-compliance with legislation and lack of enforcement (Department of Public Service Administration, 2011). According to the Public Service Anti-Corruption Strategy (2002), the accounting officers, who are the heads of departments, take the responsibility in making sure that their departments have minimum anti-corruption capacity requirements. To this end, they are obliged to report to the Department of Public Service Administration (DPSA) all the cases regarding corruption and related offences. These provisions of the strategy are quite progressive except for the fact that there are no punitive measures for non-compliance. As a result, most of the departments do not submit their corruption and related offences cases to the DPSA as required by the strategy. This makes it difficult for the DPSA to monitor the trend of unethical behaviour in the South African Public Service. According to the results of the 2009/10 MACC Audit, overall score for compliance with the MACC requirements in provincial and national government is $47 \%$. This statistics points out to a weak status of compliance. Heads of departments do not suffer any consequences for non-compliance; there are simply no punitive measures in place to encourage heads of departments to implement the strategy as required. Local Government Anti-Corruption Strategy (2006) also experiences more if not similar challenges as noted above in regard to 
the implementation of the Public Service Strategy. In a nutshell, the local government is also in shambles with regard to its fight against corruption.

Matters are even made worse on the account that Chapter 9 Constitutional institutions which are supposed to play an oversight role have got no powers to impose punitive and rehabilitative measures where they find wrong doing within the practice. The only thing that these institutions can do is to make recommendations to the department when wrong doing has been proven. Often times than not, these recommendations are not implemented. The Parliament created a Standing Committee on Public Accounts (SCOPA) to an oversight watchdog over the way taxpayers' money is spent by the executive. Every year the Auditor-General tables reports on the accounts and financial management of the various government departments, state institutions and municipalities. Accounting officers of these institutions are regularly called by this committee to report and account for the expenditure. The committee can recommend that the National Assembly takes corrective actions if necessary. Flowing from this perspective, it can be argued that this committee (SCOPA) has also suffered the same weaknesses as with the Chapter 9 Constitutional institutions as it also have no powers to institute corrective and disciplinary measures to the offenders.

\subsection{Insufficient Political Will}

Another issue that is closely related to issues of non-compliance is the question of whether there is sufficient 'political will' to combat corruption in government (Mle \& Maclean, 2011). In a number of countries the exercise of political power is, at times, motivated by private gain, hence the ongoing debate of public administration versus public management paradigm (Lam, 1997; Stivers, 2003; Sindane, 2004; Smith, 2010) in that the field of administration is veering towards reliance to market forces to the detriment of losing its publicness (Lam, 1997; Haque, 2001). In situations where corruption is widespread the expectation may be that politicians will act in the interests of a few privileged constituents instead of in the national interest or reducing the public servant call to customer seller relationship that is influenced by market related benefits to those in office (Haque, 2001) as well as the progression of the New Public Management (NPM) tendencies within the public service (Vyas-Doorgapersad, 2011). The strength of political parties, the political structure, either parliamentary or presidential, and levels of civic education may all play a role in shaping the political will for reform (AusAid, 2007) as well in relation to what Gawthrop (1998) referred to as the human side of public administration. The same can equally be said about South Africa. The president of the Republic of South Africa, Mr Jacob Zuma has reshuffled his cabinet more than three times in his first term of office amid rumours of corrupt activities that implicated some of the members of his cabinet as well as notable recommendations by the Office of the Public Protector to take action against some of the cabinet ministers who were found to been involved in maladministration and corruption. As late as 2012, the National Government has put a handful of Provincial Departments under administration in terms of section 100 of the Constitution of the Republic of South Africa of 1996 due to financial mismanagement and irregularities in one of the provinces. Many of these departments were within the Limpopo Provincial government wherein allegations of corrupt activities by political leaders have been widely reported by media (City Press, 2012) as well as opposition parties in various platforms. Among the Political Office Bearers that were affected by the intervention, some perceive actions by the Office of the President and National Government Executive as motivated by political "conspiracy" than genuine intentions to root out corruption (Seopela, 2012) while others see it as a show of political will to fight corruption within the public service. Both arguments have their own merits but they are not sufficient for a conclusive argument as indeed there were circumstances that have warranted the national intervention, in as much as politics were also playing themselves out within the Province as the run-up towards the ruling party's elective conference was drawing closer. If one is to subject the move of both the President and the National Government Executive to the Public Service Anti-Corruption Strategy which is based on four pillars, namely, prevention, detection, investigation and resolution, one will find out that the actions have been reactive and not proactive to the fight against corruption. Hence, it is argued in this article that the strong and most important political will required to sustainably reduce corrupt behaviour should put more efforts and emphasis in prevention and detection of corrupt activities without undermining the importance of investigations and resolution. This is however not yet the case, South Africa is not there yet. More efforts are seemingly invested into investigations and resolution of corrupt cases rather than prevention and detection. The risk of focusing too much on investigations and resolutions of corruption cases than on prevention and detection is reactive and highly subjective to an extent that the language of political solution is dominating the practice. It appears as if it is meant to appease the public and political opponents that the government is committed in its fight against corruption yet in reality is rather the shifting of the problems around to buy time. The implication of neglecting prevention and detection is that government allows corruption to thrive by failing to close the floodgates thereof with regimes after regimes coming to office and spend time dealing with problems created by previous regimes while compromising service delivery. In some situations alleged 
corrupt Office Bearers are just shifted in within the public service and a setup is created of replacing an alleged corrupt official with a corrupt official.

\subsection{Political deployments, low wages and an absence of meritocratic systems}

Political deployments to the public sector, low wages, and an absence of meritocratic systems exacerbate bureaucratic corruption (De Waal, 2012; Thornhill, 2012). This is to say that public officials may resort to corrupt practices to supplement inadequate public sector wages. This kind of corrupt practice is rife within the traffic officers, police and in some cases custom officials in the form of bribery and some cases, extortion. The rationale for engaging in this practice is often said to be low wages and taking bribery is viewed as a supplement to their salaries. The truth is, though low wages maybe partly responsible for that behaviour, the main reason why bribery is rife is because on one hand of the bribe taker it's difficult to detect and control and on the other side of the bribe giver the motive for getting away with an offence which will cost much than a cheap bribe is too strong.

The African National Congress (ANC) as the ruling party is under strong criticism for their policy of cadre deployment (Areff, 2012; De Waal, 2012; Thornhill, 2012). Municipal and other public service appointments are used to reward political allies, which discourages talented staff and undermines institutional performance. In these situations corruption, maladministration and mismanagement find a fertile ground to breed often leading to service delivery protests. The late then Minister for Cooperative Governance and Traditional Affairs (COGTA), Mr. Sicelo Shiceka, has conceded to this reality. The critical problem that has overwhelmed most government institutions relates to the issue of capacity constraints (Manyaka \& Madzivhandila, 2013). The Minister Shiceka acknowledged that the policy of cadre deployment has literally crippled the capacity of local government to deliver services within the country. To this effect, the Municipal Systems Amendment Bill was passed into law on the $06^{\text {th }}$ June 2011 in parliament to prevent political office bearers from being appointed to senior positions in municipalities. The graph below shows a growing trend of the service delivery protest from 2004-2010 related to the issues raised above:

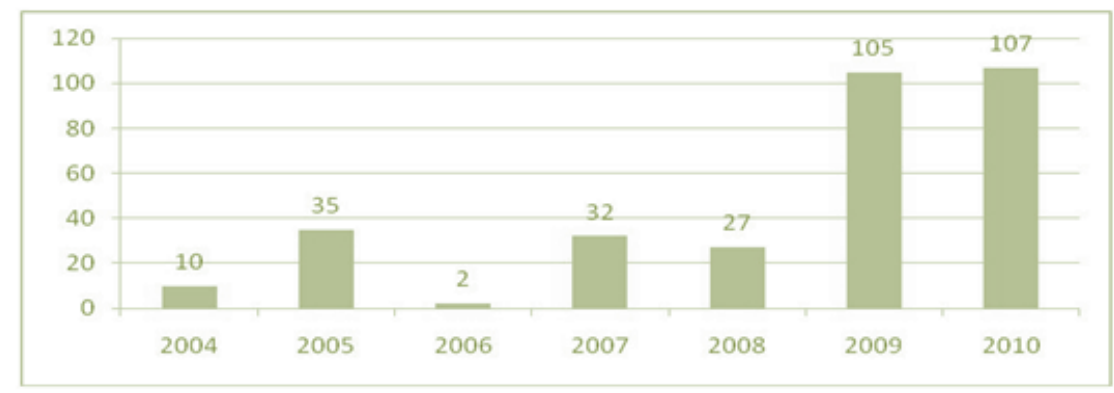

[Source: Municipal IQ Municipal Hotspots Monitor, 2011]

The passing of the Municipal Systems Amendment Bill (2011) came under cloud of the rise of service delivery protests in the country as the graph above clearly shows. Though the bill will not eradicate the challenges inherent in local government, it is believed that it is an important step in professionalising the local government and making it more responsive to the needs of the people in the long term. If this bill is fully implemented, there might be an improvement in service delivery and the subsequent reduction of service delivery protests.

\section{The Significance of Combating Corruption in the Public Sector}

Kroukamp (2006:207) points out that "corruption is especially harmful in developing countries such as South Africa due to the effect that these countries tend to have fewer resources and need to use these scarce resources in the most effective way as well as a lack of confidence in the government". Flowing from this perspective, it can be argued therefore that the overall goal in the fight against corruption in the public sector is to improve service delivery. This can be achieved by bringing sustainable reduction in corrupt behaviour and improving good governance. In fighting corruption effectively and efficiently, the government will also save a lot of money meant for public service delivery. South African public sector losses a huge amount of public funds every year (......). According to Consumer Goods Council (2006), South Africa loose between R50 Billion to R150 Billion annually due to fraud and corruption. It is not far-fetched to estimate that 
government loose between R25-billion and R30-billion (Corruption Watch, 2013) or even more alone. Too many lives could be improved with R30 billion if appropriately spend for eradicating service delivery backlogs than to go to the pockets of the corrupt few who are both politically correct and connected.

It is also worth noting that corruption does not only undermine the development goals of the country but it hits the poor the most as resources meant to assist them out of their needy conditions are diverted to the benefits of the few elites. Under these circumstances, structural inequalities are reinforced and the rich get richer as the poor get even poorer. This is a condition which is not conducive for social and political stability. Structural inequality also leads to many being denied access to education, to information, and therefore to knowledge about their rights that could enable them to challenge abuse of power and or authority. Thus, it has been argued by Uslaner (2007) that the roots of corruption lie in the unequal distribution of resources in a society. What is clear from Uslaner's argument is that corruption thrives on economic inequality. That is, economic inequality provides a fertile breeding ground for corruption - and, in turn, it leads to further inequalities (Uslaner, 2007). In light of the above, the following interventions are suggested.

\section{Recommended Interventions for Combating Corruption in the Public Sector}

The approach to fight against corruption in the South African public sector should be guided by a clear understanding of what enables corruption to thrive and equally on the best practices both locally and across the globe. Lessons learnt from successful departments and other countries should offer a rich experience on what should possibly be done going forward. It is evident however that in order to improve governance and reduce corruption, the public sector should implement its anti-corruption strategies to the fullest. Both local government and the public service are still struggling to implement their own anti-corruption strategies. It is difficult to determine the level of implementation at local government in regard to the implementation of the Local government anti-corruption strategy adopted in 2006. This can be attributed to the fact that no specific audit was conducted to measure the level of compliance with the strategy. Nonetheless, the public service is not doing well in regard to implementing the Public Service Anti-Corruption Strategy as MACC Audit results (2010) concluded that "the state of compliance is weak". This article proposes that in order for the public sector to fight corruption effectively and efficiently as desired, the following strategic approaches should be considered namely: renewed political will; a need for investment into corruption research; anti-corruption strategies must be long term and multifaceted; Reducing opportunities for corruption and changing incentives for corrupt behaviour.

\subsection{Renewed political will}

Van der Merwe (2006) cited Klitgaard (1998) to present an argument that "political will" to combating corruption is a necessary prerequisite for a successful anti-corruption work. Efforts to combat corruption are most effective when there is strong message and action of zero tolerance to corruption at the political level. In the South African public sector, political office bearers in all spheres of government need to speak and act harshly against corruption. This should be adopted as a sustainable political action until such time that it is firmly implanted in the conscience of the public service and translate into a notable reduction or total eradication of corruption. The efforts should focus more on prevention and detection as deterrence for corrupt behaviour. For this reason, there is a need to strengthen accountability tools and processes. This especially because the inadequate accountability measures are among the reasons cited for the persistent and constant unethical behaviour that continues to overwhelm public sector institutions.

\subsection{A need for investment into corruption research}

According to Ruhiiga (2009: 1090), "corruption remains a topical issue in South Africa because of its impact on civil society, governments and institutions". Following this line of argument, it is clear is a subject of interests to Public Administration scholars, civil society and business. Any subject of interest requires a comprehensive scientific research in order to know the root causes, nature and the dynamics of such a subject. Anti-corruption is one field that should be thoroughly researched more so as it is an emerging subject and has suddenly but reasonably become an important measure of good governance in the public sector. Government needs a reasonable budget to fund scientific research into corruption. Ruhiiga (2009: 1092) further argues that in dealing with corruption, one of the most serious challenges faced, is the lack of reliable information in the form of consolidated statistics on its location, extent and type". The research will be very instrumental in informing the government which areas are more problematic and possibly what should be done to prevent corruption. The public sector will be at a better position to develop anti-corruption programmes which address problematic areas and afford a better opportunity to tackle the challenges of corruption more effectively and efficiently as 
desired for improvement in service delivery from a scientifically informed perspective. Without a truly comprehensive scientific research, the public sector will continue working in the dark or under general assumption which will not produce the desired results and will also results in further loss of tax payers' money committed to wrongly targeted programmes. Corruption information management system as proposed in the Public Service Anti-Corruption Strategy needs to be established so that all the cases of corruption could be registered into a central system. This will enable the public service to monitor trends in corruption, vulnerable departments and areas so that a shaper response plan could be developed to tackle corruption.

\subsection{Anti-corruption strategies must be long term and multifaceted.}

Anti-corruption work is fundamentally about changing attitudes and behaviour. This is both difficult and time consuming. The ultimate objective is to achieve improved standards of ethics, accountability and integrity. This may require generational change. An effective anti-corruption strategy requires a multi-pronged approach. It needs to draw on successful strategies that support local reform constituencies, reduce opportunities for corruption, and provide positive and negative incentives or even target school curriculum (Auaid, 2010). This will also require a seamless political change so that the party which comes to power continues from where the previous one has left off. It will only happen if the outgoing and the incoming party have some sort of bi-partisanship in relation to key governance policy direction and would be impossible where such synergy does not exist as it is often the case with the politics of the developing world as opposed to the developed world.

\subsection{Strengthening constituencies in the fight against corruption}

Leadership commitment in the public sector is a pre-requisite for a successful programme or intervention in the fight against corruption. Any attempt to attain leadership commitment will equally require a strong political will campaigning for zero tolerance on corruption and holding public sector leaders and officials accountable on the fight against corruption. It is not simple to attain leadership commitment across the Public Sector but it is a condition without which a successful anti-corruption campaign is almost impossible. Government officials needs to be "educated about corruption and its consequences" (Van der Merwe, 2006:42) Training public sector employees on the whole concept of corruption and ethics will contribute towards building a strong and informed constituency against corruption. The DPSA has developed the training programme targeting three categories of employees in the public service namely; training for general employees, training for anti-corruption practitioners and training for investigators (DPSA, 2010). This is a positive step in the right direction towards promoting and encouraging ethical behaviour in the public sector.

\subsection{Reducing opportunities for corruption}

Empowering one of the key accountability and oversight institutions like the Auditor's General (AG), offices of the Public Service Commission (PSC), the Public Protector and Standing Committee on Public Accounts (SCOPA) with powers to take disciplinary action against wrong doing where it has been proven beyond doubt and increasing the staffing of the Public Protector to be able to carry-out its mandate without staff constraints, could play a crucial and critical role in reducing opportunities for corruption. Prevention and detection efforts should be increased and strengthened to be deterrent enough without losing focus on ensuring speedy investigative and resolution capacity for both reported and detected cases. People tend to engage in corruption because they know they can beat the system. However, if the system is strong people are less likely to engage in corruption because chances of being caught and punished are more likely. The public sector should consider a mass public anti-corruption campaign to empower the general public on how to identify and report corruption because public servants alone cannot win the war against corruption. After all, it is the ordinary citizens who bear the brunt of corruption. The members of the public should be educated on the concept of corruption and its consequences as well as how to report it. They should also be made aware of the relevant legislation that could help them in the fight against corruption such as the Protected Disclosures Act, Act No. 26 of 2000; Promotion of Administrative Justice Act, Act No. 3 of 2000; and Promotion of Access to Information Act, Act No.2 of 2000. If the members of the public are empowered, it will make it difficult for corruption to thrive in the South African public sector.

\subsection{Changing incentives for corrupt behaviour}

Van der Merwe (2006:40) argues that "effective corruption reporting mechanisms are essential aspects of anti-corruption 
systems to the extent that their absence may facilitate corruption". According to the Prevention and Combating of Corrupt Activities Act, managers in the public and private sector are required to report any case of corruption involving more than R100 000 to the police. A failure to do so may result in criminal charges against the responsible manager (National AntiCorruption Forum, 2006). This however does not imply that any corrupt transaction below R100 000 is not criminal and thus should not be reported. It only seeks to incriminate managers if transactions of that value are not reported. The same legislation requires that the Minister of Finance create a Register for Tender Defaulters, which is kept by the national treasury to prevent corrupt individuals and businesses from doing business with government. The provisions of the legislation as stipulated above should provide negative incentives for corrupt behaviour if fully and earnestly implemented. The public sector needs to step up its efforts to ensure that these pieces of legislations are fully implemented in the quest to deter corrupt behaviour. The cumulative effects of poor salaries, poor linkages between merit and promotion, and otherwise uncertain career development prospects, can foster corruption among public officials. A professional, apolitical, merit-based, and non-discriminatory public sector plays a major role in transparent and accountable government. Public sector reforms, including improved internal governance arrangements, can provide positive incentives for behavioural change. Again, a long-term commitment to reform is required, with a focus on simplifying procedures and regulations, strengthening non-discriminatory and merit-based appointment and remuneration systems, minimising discretionary powers of decision-makers, and fostering a commitment to values or codes of ethics (Auaid, 2010).

\section{Conclusion}

The article has sought out to provide an analysis of the phenomenon of corruption in the South African public sector with a view of challenges and opportunities that could be exploited to effectively reduce the extent and level of corruption. To this end, article recognises undoubtedly that the South African public sector has a sound legislative framework and strategies for combating corruption. It is rather the failure to comply with those processes and procedures due to incapacity and insufficient leadership commitment that provides opportunities for unethical, fraudulent and/or corrupt activities. At the professional level DPSA and CoGTA should consider providing technical assistance in the public service and local government respectively to build compliance capacity where sound processes and procedures are ignored, unknown or poorly understood such as conflict of interests. However, increased and strengthened political will is critically instrumental in the fight against corruption.

\section{References}

Ahmad, N. 2004. Corruption and Competition in Bureaucracy: A Cross-Country Analysis. Pakistan Economic and Social Review, 42(1/2): 61-86

Areff, A. 2012. ANC's cadre deployment drags down public service. Mail \& Guadian, 12 July, 2012.http://mg.c0.za/article/2012-07-12anc-cadre-deployment (accessed on 10/10/2012)

Australian Agency for International Development, (2007) "Tackling corruption for growth and development",

Balachandrudu, K. 2006. Understanding Political Corruption. The Indian Journal of Political Science, 67(4): 809-816

Bitarabeho, J (2003) "Curbing corruption and promoting transparency in local governments experience of Bushenyi district", Washington $\mathrm{DC}$,

Barberis, P. 2012. The managerial imperative: Fifty years' change in UK public administration. Public Policy and Administration, 28(4): 327-345

City Press, 2012. Limpopo rot: 38 cases opened. http://www.citypress.co.za/news/limpopo-rot-38 cases-opened-20120704/ (Accessed on 10.10.2013)

Clarke, J. 2010. Public Management or Managing the Public? The Frank Stacey Memorial Lecture 2009, presented at the Public Administration Committee Conference, University of Glamorgan, 8 September 2009. Public Policy and Administration, 25(1): 118

Consumer Goods Council, May Bulletin, Johannesburg, 2006

Corruption Watch. 2013. Economic impact of corruption. http://www.corruptionwatch.org.za/content/economic-implications (Accessed on 05.06.2014).

De Graaf, G. 2007. Causes of Corruption: Towards A Contextual Theory of Corruption. Public Administration Quarterly, 31(1/2): $39-86$

Denoeux, G. 2007. Corruption in Morocco: Old forces, new dynamics and a say forward. Middle East Policy, XIV(4): 134-151.

Department of Public Service and Administration, (2010) MACC Audit, Pretoria, 2009/2010

Department of Public Service and Administration, 2011 Public Sector Integrity Management Framework, Pretoria: Government printers http://www.dpsa.gov.za/dpsa2g/documents/misc/Integrity\%20Management\%20Framework.pdf Accessed on 05/05/2012

De Waal, M. 2012. Cadre deployment, cronyism and paving SA's highway to hell. Daily Marverick http://www.dailymaverick.co.za/article/ 
2012-08-03-cadre-deployment-cronyism-and-the paving-of-sas-highway-to-hell/ (Accessed on 10/10/2013)

Edwards, T. (2008) The Nuts and Bolts of Ethics, Accountability and Professionalism in the Public Sector: An ethical leadership perspective. Journal of Public Administration. 43(3.1): 77-88

Gawthrop, L.,C. 1998. 1998 John Gaus Lecture: The Human Side of Public Administration. Political Science and Politics, 31(4): 763-769

Haque, M.,S. 2001. The Diminishing Publicness of Public Service under the Current Mode of Governance. Public Administration Review, 61(1): 65-82

Kanyane, M.H.,(2005) Conflict of interest in South Africa: Unravelling the Revolving Door. Journal of Public Administration. Conference Proceedings. October 2005.

Kroukamp, H., 2006 Corruption in the South Africa with particular reference to Public sector institutions: The evil of all evils. Journal of Public Administration. 41(2.1): 206217

Lam, J.T.M. 1997. Transformation from the Public Administration to Management: Success and Challenges of Public Sector Reform in Hong Kong. Public Productivity and Management Review, 20(4): 405-418

Mafunisa, M., J. 2007 Corruption and Service Delivery in the Public Service: The case of LimpopoProvince. Journal of Public Administration. 42 (3): 260-270

Manyaka, R.K \& Madzivhandila, T.,S. 2013. The Implementation of Integrated development Plan for Service Delivery Purpose. In Sebola MP, Tsheola, JP, Phago, KG \& Balkaran S. 2013. Challenges of local government in South Africa. Sovenga. University of Limpopo.

Manyaka, R., K. \& Sebola, M.P. 2013. Ethical training for effective anti-corruption systems in the South African public service. Journal of Public Administration, 48(1): 75-88

Mle, T.R \& Maclean, S. 2011. Ethics, integrity and good governance: The case of South Africa's local sphere of government. Journal of Public Administration, 46(4):1364-1383.

Myint, U. (2000). "Corruption: Causes, Consequences and Cures," Asia-Pacific Development Journal 7(2). (http://www.unescap.org /drpad/publication/journal_7_2/myint.pdf)

National Anti-Corruption Forum (2006) Understanding the Prevention and Combating of Corrupt Activities Act, Pretoria. Available on http://www.nacf.org.za/guide-prevention-combating corrupt-activities/index.html accessed on: 05/05/2012.

Thornhill, C. 2012. Improving local government transformation in South Africa. Administratio Publica, 20(3): 128-143.

Pauw, J.C, Woods, G.,Van der Linde G.J.A., Fourie D \&Visser C.B (2009) Managing Public Money: Systems from the South: Johannesburg: Heinemann

Republic of South Africa 1996. The Constitution of the Republic of South Africa of 1996. Pretoria: Government Printers.

Republic of South Africa (2004) Prevention and Combating of Corrupt Activities Act 9 of 2004.Pretoria: Government Printers.

Republic of South Africa. 2011. Draft public service integrity management framework. Pretoria:Government Printers.

Republic of South Africa. Local government anti-corruptions strategy. Pretoria: Government Printers.

Republic of South Africa. 2011. Municipal systems amendment bill. Pretoria: Government Printers.

Ruhiiga, T.M (2009) Costing the impact of corruption on service delivery in South Africa: An exploratory overview. Journal of Public Administration, 44 (4): 10901101.

Seopela, M.2012. Limpopo under Pretoria: Abuse of power, arrogance, lies and failure of cooperative governance. Unpublished.

Sindane, A.M. 2004. Public administration versus public management: parallels, divergences, convergences and who benefits? International Review of Administrative Sciences, 70(4): 665-672

Smith, S.R. 2010. Non-profits and Public Administration: Reconciling Performance Management and Citizen Engagement. The American Review of Public Administration, 40(2): 129-152

Stivers, C. 2003. Administration versus Management: A Reading from Beyond the Boundaries. Administration and Society, 35(2): 210-230

Soliman, H \& Cable, S. 2011. Sinking under the weight of corruption: Neoliberal reform, political accountability and justice. Current Sociology, 59(6) 735-753

Transparency Internationals' Global Corruption Barometer (2013). Global Corruption Barometer 2010/11. http://www.transparency.org/country\#ZAF_PublicOpinion (Accessed on 05/06.2014)

Uslaner, E., (2007) "Corruption and the Inequality Trap in Africa: A comparative series of National public attitudes surveys on democracy, markets and civil society in Africa. Cape Town: Afro Barometer Working paper No. 69, April 2007 Also available on: http://pdf.usaid.gov/pdf_docs/PNADI728.pdf Accessed on: 05/05/2012

Van der Merwe A., (2006) The Nature and Causes of Corruption: Perceptions of KZN Public service managers and anti-corruption agents. Journal of Public Administration, 41(1): 32-46

Vyas-Doorgapersad, S. 2011. Paradigm shift from Public Administration to New Public Management: Theory and Practice in Africa. The Journal for Transdisciplinary Research in Southern Africa, 7(2): 235-250 